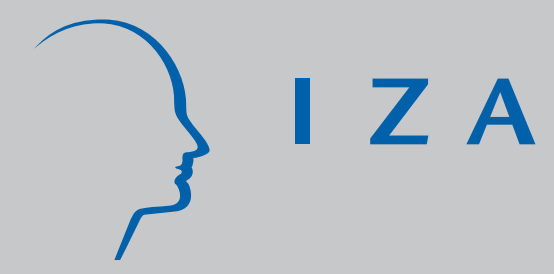

IZA DP No. 4105

\title{
Occupational Choice: Personality Matters
}

\section{Roger Ham}

P.N. (Raja) J unankar

Robert Wells

April 2009 


\title{
Occupational Choice: Personality Matters
}

\author{
Roger Ham \\ University of Western Sydney \\ P.N. (Raja) Junankar \\ University of Western Sydney \\ and IZA \\ Robert Wells \\ University of Western Sydney
}

Discussion Paper No. 4105

April 2009

IZA

P.O. Box 7240

53072 Bonn

Germany

Phone: +49-228-3894-0

Fax: +49-228-3894-180

E-mail: iza@iza.org

\begin{abstract}
Any opinions expressed here are those of the author(s) and not those of IZA. Research published in this series may include views on policy, but the institute itself takes no institutional policy positions.

The Institute for the Study of Labor (IZA) in Bonn is a local and virtual international research center and a place of communication between science, politics and business. IZA is an independent nonprofit organization supported by Deutsche Post Foundation. The center is associated with the University of Bonn and offers a stimulating research environment through its international network, workshops and conferences, data service, project support, research visits and doctoral program. IZA engages in (i) original and internationally competitive research in all fields of labor economics, (ii) development of policy concepts, and (iii) dissemination of research results and concepts to the interested public.
\end{abstract}

IZA Discussion Papers often represent preliminary work and are circulated to encourage discussion. Citation of such a paper should account for its provisional character. A revised version may be available directly from the author. 


\section{ABSTRACT}

\section{Occupational Choice: Personality Matters}

In modern societies, people are often classified as "White Collar" or "Blue Collar" workers: that classification not only informs social scientists about the kind of work that they do, but also about their social standing, their social interests, their family ties, and their approach to life in general. This analysis will examine the effect of an individual's psychometrically derived personality traits and status of their parents on the probability of attaining a white collar occupation over the baseline category of a blue collar occupation; controlling for human capital and other factors. The paper uses data from the Household Income and Labour Dynamics in Australia (HILDA) survey to estimate a random effects probit model to capture the effects on the probability of being in a white collar occupation. The results are then examined using the average marginal effects of the different conditioning variables over the whole sample. The analysis confirms the previous findings of human capital theory, but finds that personality and parental status also have significant effects on occupational outcomes. The results suggest that the magnitude of the average marginal effect of parental status is small and the effect of the personality trait "conscientiousness" is large and rivals that of education. Finally, estimates of separate models for males and females indicate that effects differ between the genders for key variables, with personality traits in females having a relatively larger effect on their occupational outcomes due to the diminished effects of education.

JEL Classification: J24

Keywords: occupational choice, personality, human capital, dynasty hysteresis

Corresponding author:

P.N. (Raja) Junankar

School of Economics and Finance

College of Law and Business

Campbelltown Campus

University of Western Sydney

Locked Bag 1797

Penrith South DC, NSW 1797

Australia

E-mail: raja.junankar@uws.edu.au 


\section{Introduction $^{1}$}

One of the major features of labour markets, compared to other markets within an economy, is the large degree of heterogeneity found within the commodity that is exchanged, labour services. The two sources of this heterogeneity in labour markets come from the varied number of roles demanded to be filled by labour and the differing characteristics of individuals who supply their labour services within markets.

Firstly, labour services differ in terms of different knowledge, physical actions, tasks, equipment, environmental conditions, and ultimately different output. Yet despite these differences they all have a commonality in requiring human beings to provide these services qualified by these factors. The number of labour types that exist in the labour market can be effectively limitless; however, labour is often categorised into broad groups in which two individuals with similar traits can be considered close substitutes, and these groups are known as occupations (Boskin 1974).

There are numerous occupations in the labour market, and consequently various attempts to define and analyse different aggregations exist. These include and are not limited to: social status

\footnotetext{
${ }^{1}$ This article is part of the PhD thesis in progress of Robert Wells. The authors would like to thank Natalie Bosch, Ulises Garcia, Paul Frijters, Tony Beatton and participants at a Brown Bag seminar at the Queensland University of Technology for the useful comments and helpful feedback in the process of this research.

This paper uses unit record data from the Household, Income and Labour Dynamics in Australia (HILDA) Survey. The HILDA Project was initiated and is funded by the Australian Government Department of Families, Housing, Community Services and Indigenous Affairs (FaHCSIA) and is managed by the Melbourne Institute of Applied Economic and Social Research (MIAESR). The findings and views reported in this paper, however, are those of the authors and should not be attributed to either FaHCSIA or the MIAESR

The data used in this paper was extracted using the Add-On package PanelWhiz for Stata ${ }^{\circledR}$. PanelWhiz (http://www.PanelWhiz.eu) written by Dr. John P. Haisken-DeNew (john@PanelWhiz.eu). See Haisken-DeNew and Hahn (2006) for details. The PanelWhiz generated DO file to retrieve the data used here is available from me the authors on request. Any data or computational errors in the paper due to the authors.
} 
based ranking systems (Jones \& McMillan 2001; Le \& Miller 2001); Holland’s six occupational types (Larson et al. 2002; Barrick et al. 2003; Porter \& Umbach 2006; Rosenbloom et al. 2008); the ranking of occupations by skill -unskilled, semi-skilled, skilled, etc- (Darden 2005); and attempts to both objectively and subjectively define good jobs and bad jobs (Junankar \& Mahuteau 2005; Mahuteau \& Junankar 2008).The main aggregation of occupations is the dichotomy of white collar and blue collar occupations. This research will investigate what factors influence an individual's attainment of a white collar or blue collar occupation. White collar occupations consist of non-manual, office related, occupations. In white collar occupations, individuals typically wear business attire consisting of a white shirt with a collar to support a tie. Examples of white collar occupations include professionals, clerical workers, sales people and managers. Blue collar occupations consist of manual, industrial, occupations. Blue collar occupations derive the term, blue collar, from the fact they typically require overalls that were at some stage commonly blue. This particular view of blue collar and white collar occupation differs to its usage in the previous literature as we discuss later in the literature review. The use of the definition is beneficial to this research as it highlights neither white collar or blue collar occupations are ubiquitously superior to the other.

The second way in which labour services, as a commodity, can vary is the differing characteristics of individuals who supply the labour. Human beings vary greatly in their characteristics and therefore it is not logical to expect them to be easily classified as an homogenous commodity. Economic theory recognises that individuals exhibit differences in both their productive capabilities and their preference for the varieties of utility and disutility associated with the supplying of labour. Consequently, we expect that individuals are not equally 
suited to each role and thus these differences are contributing determinants to an individual's occupational outcome, that is, which of the varied labour market roles they choose.

Economic theory has various explanations for these differences. One explanation which is predominant in labour economics analysis is human capital theory. Human capital theory is focused on the effects of education, experience and an individual's innate ability in determining their productivity in various tasks and the utility they can derive from various remunerations from labour (Becker 1993; Becker 1996). Another source of heterogeneity that can affect an individual's outcome is the achievement of their parents. For example, if an individual's father or mother achieves a high occupation status, then this social status can assist in the achievement of a higher occupation status for the individual. This phenomenon of intergenerational occupational transfers is referred to as "dynasty hysteresis" (Bradley 1991). A recently expanding area within economics is the combination with psychology to use psychometrically determined personality traits to explain economic behaviour (Borghans et al. 2008). These traits affect outcomes by both influencing the productive capabilities and the preferences an individual may exhibit in the labour market, and consequently act as a contributing determinant to the attainment of a white collar or blue collar occupation. The determinants of white versus blue collar outcomes examined in this paper are primarily those focused on the heterogeneity between individuals. Blau (1956) points out that these determinants based on the heterogeneity between individuals and labour tasks are only part of the factors governing occupational outcomes. Long run aspects such as technology and the natural and economic environment can systematically change the occupational choices of all individuals. This is due to changes made to the nature of the occupations, the labour market and economy in general. Whilst this is true, these long term influences are not included in the present analysis

This paper examines how the two sources of heterogeneity in labour markets influence occupational outcomes. Occupations are assigned to individuals through the interactions of the demand side factors for various types of labour services by firms and the supply decisions of 
individuals. Individuals are free to choose the occupation that maximises their utility given the constraints imposed by profit maximising firms.

Specifically the research will examine if an individual's occupational choice between a white and blue collar occupation is influenced by the heterogeneity in the characteristics between individuals. This research will also examine the determination of occupational choice by parental status and personality factors. We use the Household Income and Labour Dynamics in Australia (HILDA) data, a dataset not currently used in occupational choice analysis, within a discrete choice panel model of the probability of being in a white collar occupational.

\section{Developments in Labour Market analysis}

Wage determination has been the primary focus in the labour economics literature. The primary focus of the wage determination literature is on human capital theory and states that wages should increase at a decreasing rate with education and experience (Mincer 1974). Recent work by Heckman, Lochner \& Todd (2003) shows that Mincer's model of wage determination is a misspecification. The estimation of wage determination models, such as Mincer's model, requires that wages fully adjust to compensate for differences in the characteristics of labour, both in the job and the individuals, as predicted by Smith (1993 reprint) as early as 1776 in his "An inquiry into the nature and causes of the wealth of nations". The ability of wages to adjust may be restricted due to the large number of different influences thought to affect wages (Ehrenberg \& Smith 2006; Friedman 2007). These influences include: sticky wages; unions; monopsonies and other market imperfections; efficiency wages (Ehrenberg \& Smith 2006); disequilibrium rents being a source of earning (Bowles et al. 2001a); and various institutional 
and sociological factors (Kaufman \& Hotchkiss 2006). The modelling of an individual's occupational choice by-passes these issues as only individual behaviour is required to alter, and not wages, in order to observe the effect of labour market characteristics.

The first modern examination of occupational choice using discrete choice econometrics was Boskin (1974) which was closely followed by Schmidt and Strauss (1975). Boskin conducted an analysis of the effects of an individual's conditional wages that is wages based on their various productive characteristics, and returns for a particular occupation, on the probability that an individual will choose that occupation. Schmidt and Strauss (1975) examined the effects that variables from by human capital theory, such as education, experience, gender and racial group, have on the individual outcomes. Recently, Bjerk (2007) estimated a random effects probit model of being in a white collar or blue collar occupation and finds that education has a positive effect in the attainment of a white collar occupation. It should be noted that Bjerk's definition of the dichotomy differs in that it is focused on good jobs and bad jobs as opposed to the that of manual and non-manual occupations. Currently, the bulk of the literature examines these human capital effects with various different focuses. These include their influences on wages (Mincer 1974; Meng \& Miller 1995; Stevens 2003; Yu 2004), occupational outcome (Schmidt \& Strauss 1975; Bradley 1991; Orazem \& Mattila 1991; Mwabu \& Evenson 1997; Pal \& Kynch 2000; Harper \& Haq 2001; Le \& Miller 2001; Yuhong \& Johnes 2003; Botticini \& Eckstein 2005; Nasir 2005; Bjerk 2007; Hennessy \& Rehman 2007; Croll 2008), choice of education achievement (Schweitzer 1971; Turner \& Bowen 1999; Montmarquette et al. 2002), gender and racial differences in occupational outcomes (Borooah 2001; Borooah \& Mangan 2002; Borooah \& Iyer 2005), the potential heterogeneity of human capital including education, experience and 
ability (Shaw 1984; Paglin \& Rufolo 1990; Neal 1995; Bratti \& Mancini 2003). This paper extends the existing literature by examining an additional set of determinants, namely personality traits and parental background.

The status of an individual's parents within a society has been argued to have an effect on occupational achievement of their offspring. This phenomenon is referred to as “dynasty hysteresis” (Bradley 1991). Laband \& Lentz (1983) argue that dynasty hysteresis is due to the ease with which human capital can be transferred, including that of ability, between parents and offspring. Alternatively, other work has examined the transmission of time preferences and the preferences towards leisure between generations resulting in such hysteresis (Doepke \& Zilibotti 2005). Akerlof (1997) devised a model based on individual pursuit of social status with two conflicting forces, this is known as the theory of social distances. The first of the two conflicting forces in Akerlof's model is the desire to succeed and achieve high social status, an idea previously examined as early as 1899 in Veblen's “the theory of the leisure class” (1998). The second was the desire to conform and fit in with one's peer group leading to an individual born with parents of lower status not desiring to achieve. Another possible reason for dynasty hysteresis is the transfer of personality traits (Bowles \& Gintis 2002; Blanden et al. 2007) . Various works have examined the effects of parental social status and found it a valid determinant of occupational outcomes. (Tachibanaki 1980; Laband \& Lentz 1983; Bradley 1991; Connolly et al. 1992; Constant \& Zimmermann 2003; Sacerdote 2005; Tsukahara 2007; Croll 2008). 
The examination of personality traits within the field of economics is an important step forward to better understand individual behaviour. Heckman and Rubinstein (2001) state that personality traits are the 'dark matter' of economics. Economics has long attributed seemingly irrational behaviour, that is behaviour which does not in align with the majority, to individual differences in preferences (Becker 1996). For example see the analysis of criminal behaviour (Hellman 1980). These apparent differences in personality can explain differences in behaviour. Previously it had been argued that preferences and personality were not a meaningful way to explain behaviour due to the huge degrees of freedom that could be applied in assigning traits to behaviour, meaning that all personality based explanations were of an ad hoc manner (Caplan 2003), and the lack of implementation of these factors was due to the inherent difficulties in measuring personality traits (Heckman \& Rubinstein 2001). McCrae and Costa (2003, pg. 25) define personality traits as "dimensions of individual differences in tendencies to show consistent patterns of thoughts, feeling, and actions”. This definition highlights that personality traits are far from perfect predictors or the sole determinants of an individual's behaviour but reflect general propensities in which an individual with a high level of a particular trait is more likely to engage in a particular activity, ceteris paribus. The science of psychology has long addressed the measurement problem of "difficult to observe phenomena", such as personality traits. To this end psychologists have embraced the statistical technique of factor analysis in order to construct various tests and instruments to capture aspects of the human psyche, including personality traits and aspect of cognitive intelligence (Borghans et al. 2008). Factor analysis is a statistical technique which attempts to find if there are a number of common underlying unobserved factors which govern the behaviour of groups of variables (Child 2006) and it is these factors which represent psychological traits. 
Personality psychology, having achieved a relative consensus, has discovered that, despite the argued infinite degrees of freedom theorised to be attributable to differences in an individual's underlying personality, personality traits can at a broad level be seen to be governed by five factors (Goldberg 1993). The Five Factor Model (FFM) consists of five broad dimensions of personality traits -summarised by the mnemonic phrase OCEAN- which are: openness to experience; conscientiousness; extraversion; agreeableness; and neuroticism (McCrae \& Costa 2003). Openness to experience can be defined as a trait associated with being accepting of new ideas and alternative points of view, appreciative of new concepts, imaginative and creative and generally inquisitive and curious. Conscientiousness is the trait that is associated with diligence, self discipline, punctuality, and hard work. Extraversion is the trait associated with being outgoing, energetic and talkative. Agreeableness is the trait associated with being warm, friendly, compassionate and empathetic. Finally, neuroticism is the trait that is associated with the ease which negative thoughts and feelings can affect an individual and is associated with traits such as irritability, being 'thin skinned' and anxious. Each of these dimensions also possesses a negative in which individual experience traits that are generally the opposite. Table 1 taken from McCrae and Costa (2003) provides a summary of characteristics that are associated with an individual's level of a particular personality trait, and reflects the negative (low score) as well as positive (high score) aspects of each trait. 
Table 1: Examples of the characteristics exhibited by people who score high and low in various personality traits

\begin{tabular}{|c|c|c|}
\hline Personality trait & Low Scorer & Higher scorer \\
\hline Openness & $\begin{array}{l}\text { Favours conservative values } \\
\text { Judges in conventional terms } \\
\text { Uncomfortable with complexities } \\
\text { Moralistic }\end{array}$ & $\begin{array}{l}\text { Values intellectual matters } \\
\text { Rebellious, nonconforming } \\
\text { Unusual thought processes } \\
\text { Introspective }\end{array}$ \\
\hline Conscientiousness & $\begin{array}{l}\text { Eroticizes situations } \\
\text { Unable to delay gratification } \\
\text { Self-indulgent } \\
\text { Engages in fantasy, daydreams }\end{array}$ & $\begin{array}{l}\text { Behaves ethically } \\
\text { Dependable, responsible } \\
\text { Productive } \\
\text { Has high aspiration levels }\end{array}$ \\
\hline Extraversion & $\begin{array}{l}\text { Emotionally bland } \\
\text { Avoids close relationship } \\
\text { Overcontrol of impulses } \\
\text { Submissive }\end{array}$ & $\begin{array}{l}\text { Talkative } \\
\text { Gregarious } \\
\text { Socially poised } \\
\text { Behaves assertively }\end{array}$ \\
\hline Agreeableness & $\begin{array}{l}\text { Critical, sceptical } \\
\text { Shows condescending behaviour } \\
\text { Tries to push limits } \\
\text { Expresses hostility directly }\end{array}$ & $\begin{array}{l}\text { Sympathetic, considerate } \\
\text { Warm, Compassionate } \\
\text { Arouses liking } \\
\text { Behaves in a giving away }\end{array}$ \\
\hline Neuroticism & $\begin{array}{l}\text { Calm, relaxed } \\
\text { Satisfied with self } \\
\text { Clear-cut personality } \\
\text { Prides self on objectivity }\end{array}$ & $\begin{array}{l}\text { Thin-skinned } \\
\text { Basically anxious } \\
\text { Irritable } \\
\text { Guilt-prone }\end{array}$ \\
\hline
\end{tabular}

Source: McCrae and Costa 2003

In psychology, a body of research has concluded that personality variables do have an impact on labour market outcomes (Barrick \& Mount 1991; Larson et al. 2002; Barrick et al. 2003; Ozer \& Benet-Martinez 2006; Furnham \& Fudge 2008). Barrick and Mount (1991) put forward a number 
of hypotheses in their meta-analysis of the previous research within psychology on the effect of the five factor model. Conscientiousness is argued to carry a ubiquitously positive effect on labour market outcomes as individuals who possess this trait are often hardworking, productive, punctual, organised and accepting of responsibility. The paper also hypothesises that openness has an effect on the ability of individuals to be trained and thus also carry a highly positive value. Neuroticism was argued to be negatively valued as individuals who experience negative feelings more intensely might be less productive due to their distress. The two social dimensions of agreeableness and extraversion to personality were argued to be valued primarily in social occupations. Barrick and Mount (1991) found that conscientiousness and openness behaved as predicted, extraversion was valued in both social jobs and training while agreeableness and neuroticism are observed to have no effect on labour market outcomes. Barrick and Mount (1991) argue that the lack of an observed effect with regard to neuroticism may be due to a sample selection bias as you require a minimum amount of emotional stability -the negative of neuroticism- to achieve a position in the labour market. Economic theory has put forward a couple of models on how personality factors can be incorporated into the utility maximising behaviour of individuals. Borghans et al. (2008) provide a theoretical model on how personality traits can be viewed in terms of constraints, or rather as capacity, which only affect the relative ability of some tasks and not others. Another potential mechanism through which personality traits may influence economic outcomes is by incentive-enhancing preferences (Bowles et al. 2001b). Individuals who possess certain characteristics may be more reactive to incentives as they have a lower marginal cost of increased effort. In practical terms these two theoretical models of how personality influences utility maximising behaviour are similar in that they both influence the relative utility of an action 
The empirical work on the economics of personality is small but growing. The first study of personality in the field of occupational choice was that of Filer (1983). Filer, using a sample from a recruiting firm, was able to relate the results of individuals to the Guildford-Zimmerman temperament survey and their corresponding occupational outcomes. The Guildford Zimmerman survey is a predecessor to the FFM and many of it traits can be nested within the parsimonious structure of the FFM. The findings seem to indicate that traits associated with consciousness and emotional stability -negative of neuroticism- are valued more as one progresses from blue collar to white collar occupations. Heckman, Stixrud \& Urzua (2006) provide an analysis of a wide variety of outcomes including: education; crime; smoking; teenage pregnancy; and, importantly to this study, the probability of being in a white collar occupation. They argue that these outcomes are affected by the personality traits of locus of control and self esteem, cognitive ability and education. They use a model designed to collapse cognitive and personality variables into two single underlying factors and which can handle any issues of measurement bias and reverse causation. The main finding of Heckman, Stixrud \& Urzua (2006) is that personality traits have an effect that rivals cognitive ability and may be even greater and this effect is much more pronounced in females.

The stability of personality has been a large area of debate within the literature on psychology. McCrae and Costa (2003) provide evidence to suggest that personality, as measured by the five factor model, is relatively stable with adults over time and argue that the underlying factors stem from, as yet, undetermined biological bases. However, observed behaviours determined by these stable psychological traits will vary according to the context that individuals find themselves in. 
This theory of the cause and stability of personality traits supports the idea of early intervention; Heckman (2008) reviews evidence that much of the biological formation of the human mind can vary in early childhood development with the environment, in which the biology forms..

Evidence suggests that adult personalities are relatively stable at the broad level of the five factor model even over extended periods of time; however, this can be altered in extreme cases such as intensive psychotherapy and modifications to the brain (McCrae \& Costa 2003). The stability of personality is a complex issue that has yet to be fully resolved and is outside the scope of this research. In this work, personality is treated as stable. This is on the basis that personality within adults, such as the working age individual, is relatively stable over the period of the dataset and at the broad level definitions of the five factor model (McCrae \& Costa 2003).

Mueller and Plug (2004) in their study on wage determination, using the five factors provided by the Wisconsin longitudinal study, find that both agreeableness and neuroticism have a negative effect on wages and that openness has a positive effect on wages. Similarly Nyhus \& Pons (2005), using a sample from the Dutch population, found neuroticism had a negative value. They argue that the mechanism behind the negative sign for agreeableness is that individuals who are agreeable are less assertive and therefore may not be able to bargain and manipulate their way into superior labour market outcomes. Other studies in the economics of personality have focused on wage determination but often not using the five factor model (Bradley 1991; Brandstätter 1997; Mueller \& Plug 2004; Groves 2005; Nyhus \& Pons 2005; Cole 2007; Semykina \& Linz 2007; Rosenbloom et al. 2008; Swope et al. 2008). To summarise, even though the literature in labour economics is dominated by wage determination, there is a strand which focuses on occupational choice. Whilst this, like wage 
determination, is weighted toward human capital theory, the occupational choice literature has also identified dynastic hysteresis and psychological personality traits as important in determining outcomes. The latter has involved the melding of economics with psychology and this has enriched occupational choice modelling. An interesting aspect of the development within the economics of psychology and occupational choice is the utilization of the five factor model to identify basic psychological traits. This paper builds on that literature estimating a discrete choice model which focuses on the influence of the five psychological factors and dynastic hysteresis on the probability of occupational outcome within the blue collar/white collar dichotomy.

\section{Data}

This analysis uses data from the Household Income and Labour Dynamics in Australia (HILDA) Surveys. HILDA is a nationally representative dataset of Australia consisting of 7,682 households containing 19,914 individuals as of wave one (Watson 2008). The survey, which is now in wave six, follows the same individuals with each wave and the sample is designed to grow and change in the same manner as the population does naturally. The survey collects a wide array of data on the behaviour and characteristics of individuals. The HILDA survey contents include, for our interests, the occupational outcome, the highest level of education, parental occupation and social status, psychometrically validated measures of the personality traits in the five factor model, and other general demographic variables, such as age and gender, for an individual. The data were compiled into files for analysis using PanelWhiz (Haisken- 
DeNew \& Hahn 2006). This dataset has not been previously used in the analysis of occupational outcomes.

The dependent variable is a binary variable which represents the outcome of a white collar occupation with the value of one or a blue collar occupation with the corresponding value of zero. The dependent variable was derived using the one digit ASCO coding of occupations (Australian Bureau of Statistics \& Australian Department of Employment Education Training and Youth Affairs 1997) provided within the HILDA data set. As previously stated, the definition that is applied throughout this analysis is based on manual labour versus non-manual labour. Using this definition, Managers, Administrators, Professionals, Associate Professionals, Clerical, Sales and Service workers are considered white collar occupations and consequently, Tradespersons, Production workers, Transport Workers, and Labourers are blue collar occupations. Whilst the top occupations, such as managers and professionals, are all in the white collar group, there are some individuals at low skill levels who are divided between white collar and blue collar occupations ${ }^{2}$. Thus, it is not possible to interpret white collar occupations as always higher, in terms of utility, than blue collar occupations as a large number of occupations in the latter category are arguably superior to some of those designated as white collar. This is highlighted by Carol and Parry (1969) who in their cost-benefit analysis of various occupations find that certain occupations in the blue collar occupation have higher returns when the costs of education are accounted for.

\footnotetext{
${ }^{2}$ It should be noted that a three tier system of blue collar, white collar and professionals is often used in the literature. This definition may indeed be more meaningful but the true meanings of blue and white collar are lost in this process and thus this definition is not useful for the purpose of this analysis.
} 
Research in labour economics has long examined the effects of education on labour market outcomes. This research indicates that the approach used in Mincer (1974) specifying that education as years of schooling and its square is inappropriate due to 'credentialism' effects (Park 1999; Heckman et al. 2003; Yu 2004; Leigh 2008). Education is specified here as the highest education achievement measured in a series of binary variables to capture the non-linear effects of education on occupational choice. Other standard human capital variables such as age and age squared are used as a proxy for experience. A caveat for this study is the omission of a measure of cognitive intelligence, which can be argued to bias the returns from education; however, research shows that measured intelligence scores have a limited impact on the labour market outcomes of individuals (Cawley et al. 1997; Cawley et al. 2001). This conclusion does not mean that intelligence is unimportant, just that it may not be in short supply (Bowles et al. 2001a).

The analysis uses two measures of parent's social status in order to more completely capture any possible dynastic effects. The first measure is a binary variable of the parent's occupational status with the same dichotomy of white and blue collar. The second measure is the parent's social status as ranked by the ANU4 (Jones \& McMillan 2001). This measure is developed as an index of various socioeconomic characteristics, for example income, education, occupation, etc., The index weights are derived using path analysis in order to minimise the direct effect of education on social status and maximize its indirect effect on other outcomes. Jones and McMillan (2001) find that various measures of social status tend to be highly correlated despite differences in specification. 
Personality traits are a complex phenomenon to observe and measure, and because of this, they differ from other variables in this study. The measurement of individual characteristics in psychology is based on factor analysis (Borghans et al. 2008). Factor analysis is a statistical technique which takes a large number of variables, or facets, and examines if there are a smaller number of latent variables, or factors, underlying the relationship, that is, it examines if these variables tend to converge with each other and be distinct from other groups of converged variables (Child 2006). The methodology is the basis for the creation of psychometric tests and is behind the measurement of cognitive intelligence and the personality traits used in this analysis. The HILDA survey in wave five used a modification of the test developed by Saucier (1994). Saucier (1994) developed a short test in which, individuals assess their personality compared to a list of adjectives. The HILDA dataset takes thirty of Saucier's forty variables and an additional six from other sources (Losoncz 2007). Losoncz (2007) provides an analysis of the psychometric properties of the personality traits collected within the HILDA survey and finds that indeed the five factor model is replicated. Losoncz (2007) does not provide a content analysis to ensure the variables examined are those which are those desired; however given that they are taken from a variety of other studies the content should be considered fairly valid. Losoncz (2007) assessment of the convergent and discriminant validity of the measure states that while the HILDA variables are not optimal but are an adequate representation of the underlying personality traits. Losoncz (2007) also conducts a predictive validity test and finds that the measures do correlate with many of the variables within the previous literature. It should be noted that based on the argument of the relative stability of personality traits captured by the five factor model, the measure from period five will be treated as the personality of the individual in all sample periods. 
To highlight the properties of the dataset, summary statistics for the 25,638 observation that are used are presented for the complete sample, the male $(\mathrm{N}=13,402)$ and female $(\mathrm{N}=12,596)$ subsamples in Tables 2 and 3 respectively. 
Table 2: Summary statistics of continuous variables

\begin{tabular}{|c|c|c|c|c|}
\hline \multicolumn{5}{|c|}{ Summary statistics for all sample } \\
\hline Variable & Mean & Std. Dev. & Min & Max \\
\hline \multicolumn{5}{|l|}{ Age } \\
\hline Age & 39.7374 & 12.0740 & 15 & 83 \\
\hline age squared & 1724.8300 & 985.8578 & 225 & 6889 \\
\hline \multicolumn{5}{|l|}{ Personality } \\
\hline Agreeableness & 5.3713 & 0.8781 & 1 & - \\
\hline Conscientiousness & 5.1349 & 1.0116 & 1 & 7 \\
\hline Emotional stability & 5.1499 & 1.0424 & 1 & 7 \\
\hline Extraversion & 4.4812 & 1.0842 & 1 & 7 \\
\hline Openness & 4.3252 & 1.0220 & 1 & 7 \\
\hline \multicolumn{5}{|l|}{ Parent Status } \\
\hline Father's ANU4 & 45.3591 & 21.9176 & 0 & 100 \\
\hline Mother's ANU4 & 39.4311 & 22.5109 & 0 & 100 \\
\hline \multicolumn{5}{|c|}{ Summary statistics for male sub sample } \\
\hline \multicolumn{5}{|l|}{ Age } \\
\hline age & 40.1588 & 12.1746 & 15 & 81 \\
\hline age squared & 1760.9370 & 1012.7880 & 225 & 6561 \\
\hline \multicolumn{5}{|l|}{ Personality } \\
\hline Agreeableness & 5.1253 & 0.8931 & 1 & 7 \\
\hline Conscientiousness & 5.0109 & 0.9991 & 1.1667 & 7 \\
\hline Emotional stability & 5.1118 & 1.0307 & 1 & 7 \\
\hline Extraversion & 4.3331 & 1.0172 & 1 & 7 \\
\hline Openness & 4.3590 & 1.0064 & 1 & 7 \\
\hline \multicolumn{5}{|l|}{\begin{tabular}{|l|} 
Parent Status \\
\end{tabular}} \\
\hline Father's ANU4 & 44.9069 & 21.9466 & 0 & 100 \\
\hline Mother's ANU4 & 38.9240 & 22.5286 & 0 & 100 \\
\hline \multicolumn{5}{|c|}{ Summary statistics for female sub sample } \\
\hline \multicolumn{5}{|l|}{ Age } \\
\hline age & 39.3011 & 11.9537 & 15 & 83 \\
\hline age squared & 1687.4590 & 955.7803 & 225 & 6889 \\
\hline \multicolumn{5}{|l|}{ Personality } \\
\hline Agreeableness & 5.6259 & 0.7850 & 2 & 7 \\
\hline Conscientiousness & 5.2633 & 1.0085 & 1 & 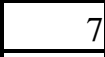 \\
\hline Emotional stability & 5.1893 & 1.0530 & 1.3334 & 4 \\
\hline Extraversion & 4.6345 & 1.1293 & 1 & 7 \\
\hline Openness & 4.2902 & 1.0367 & 1 & 7 \\
\hline \multicolumn{5}{|l|}{\begin{tabular}{|l|} 
Parent Status \\
\end{tabular}} \\
\hline Father's ANU4 & 45.8273 & 21.8786 & 0 & 100 \\
\hline Mother's ANU4 & 39.9561 & 22.4813 & 0 & 100 \\
\hline
\end{tabular}


Table 3: Summary statistics of binary variables

\begin{tabular}{|c|c|c|c|c|c|c|c|}
\hline & Proportion & Proportion & Proportion & & Proportion & Proportion & Proportion \\
\hline & pooled & male & female & & pooled & male & female \\
\hline Dependant variable & & & & Industry & & & \\
\hline white-collar & 0.6981 & 0.5889 & 0.8111 & Agriculture & 0.0410 & 0.0534 & 0.0280 \\
\hline Gender & & & & Mining & 0.0128 & 0.0230 & 0.0022 \\
\hline Female & 0.4913 & & & Gas \& water & 0.0071 & 0.0123 & 0.0017 \\
\hline Marital status & & & & Electricity & 0.0662 & 0.1123 & 0.0185 \\
\hline Married & 0.5791 & 0.6080 & 0.5493 & Construction & 0.0378 & 0.0468 & 0.0284 \\
\hline De facto & 0.1428 & 0.1416 & 0.1440 & Wholesale & 0.1144 & 0.0997 & 0.1296 \\
\hline Separated & 0.0293 & 0.0248 & 0.0340 & Retail & 0.0424 & 0.0339 & 0.0511 \\
\hline Divorced & 0.0553 & 0.0395 & 0.0717 & Transport & 0.0370 & 0.0539 & 0.0195 \\
\hline Widow & 0.0089 & 0.0025 & 0.0156 & Communication & 0.0202 & 0.0260 & 0.0143 \\
\hline State & & & & Finance & 0.0383 & 0.0346 & 0.0421 \\
\hline $\mathrm{VIC}$ & 0.2498 & 0.2550 & 0.2445 & Property & 0.1177 & 0.1221 & 0.1132 \\
\hline QLD & 0.2081 & 0.2043 & 0.2120 & Government & 0.2823 & 0.3437 & 0.2187 \\
\hline SA & 0.0836 & 0.0838 & 0.0834 & Education & 0.1167 & 0.0618 & 0.1735 \\
\hline WA & 0.0974 & 0.1062 & 0.0883 & Health & 0.1245 & 0.0452 & 0.2067 \\
\hline TAS & 0.0312 & 0.0268 & 0.0358 & Culture & 0.0303 & 0.0321 & 0.0285 \\
\hline $\mathrm{NT}$ & 0.0071 & 0.0081 & 0.0062 & Personal & 0.0397 & 0.0390 & 0.0405 \\
\hline $\mathrm{ACT}$ & 0.2498 & 0.0260 & 0.0223 & $\begin{array}{l}\text { Country of } \\
\text { origin }\end{array}$ & & & \\
\hline Education & & & & $\begin{array}{l}\text { English } \\
\text { speaking } \\
\text { nations }\end{array}$ & 0.1199 & 0.1313 & 0.8139 \\
\hline PhD or Masters & 0.0473 & 0.0525 & 0.0418 & $\begin{array}{l}\text { Non English } \\
\text { speaking nation }\end{array}$ & 0.0752 & 0.0725 & 0.1081 \\
\hline Graduate diploma & 0.0759 & 0.0601 & 0.0922 & Parent Status & & & \\
\hline Bachelor degree & 0.1726 & 0.1563 & 0.1895 & $\begin{array}{l}\text { Dad is white- } \\
\text { collar }\end{array}$ & 0.5548 & 0.5385 & 0.5717 \\
\hline Advanced diploma & 0.1063 & 0.0993 & 0.1135 & $\begin{array}{l}\text { Mum is white- } \\
\text { collar }\end{array}$ & 0.5640 & 0.5472 & 0.5813 \\
\hline Certificate 3 or 4 & 0.2039 & 0.2809 & 0.1242 & Time periods & & & \\
\hline Certificate 1 or 2 & 0.0118 & 0.0104 & 0.0133 & $\mathrm{t} 2$ & 0.1534 & 0.1550 & 0.1519 \\
\hline Certificate NA & 0.0024 & 0.0015 & 0.0034 & $\mathrm{t} 3$ & 0.1598 & 0.1617 & 0.1578 \\
\hline \multirow[t]{3}{*}{ Year 11 or less } & 0.2354 & 0.2051 & 0.2667 & $\mathrm{t} 4$ & 0.1683 & 0.1681 & 0.1686 \\
\hline & & & & $\mathrm{t} 5$ & 0.1901 & 0.1875 & 0.1927 \\
\hline & & & & $\mathrm{t} 6$ & 0.1775 & 0.1760 & 0.178 \\
\hline
\end{tabular}


Table 2 shows that only a small set of the variables used in the analysis are not binary. The relatively large number of binary variables used in the model does allow for the modelling of phenomena not easily measured as a continuous random variables. Education, as argued previously, is examined as a series of binary variables in order to capture any possible heterogeneity or non-linearity which may exist in education. The personality variables based on the HILDA data surveys question are continuous variables that can take on any value in the closed interval one to seven. The scale of this measure is essentially arbitrary with only the relative importance of higher levels of this trait focused on in this analysis. The ANU4 measure of social status is a variable valued to one decimal place, between 1 and 100 with increasing levels representing higher achievements in society

From the descriptive statistics we can see that the proportion of individuals in a particular occupation states is in white collar occupations with females have a high representation in this category. The key difference between the genders from the summary statistics is gender concentration in certain industries such as mining and construction for males and health and education for females. In addition, males seem to have a much higher proportion of a certificate 3 or 4 education which includes completed qualifications as tradesperson. It is possibly due to these reasons that we can see the unconditional probability of males in white collar jobs being lower than that for females. This research shall, as is common in the literature, analyse males and females separately whether these factors control for this difference. 
In summary, this analysis will use the HILDA dataset, a nationally representative and detailed sample of the population of Australia that has yet to be used in the examination of occupational choice. The dependent variable is derived using the ASCO coding of occupations. Independent variables shall consist of a series of education binary variables, derived social status, psychometrically assessed personality traits and various control variables.

\section{Methodology}

The focus of this analysis is the white and blue collar dichotomy. The dependent variable is binary, and the analysis uses a discrete choice econometric model for the conditional analysis of the two mutually exclusive outcomes. Discrete choice models capture behaviour by estimating models based on the latent utility stemming from a choice and its influence on the probability of an individual making a choice given their associated characteristics (Amemiya 1981). The probability score conditioned by the independent variables should be interpreted as the probability of an individual being in a white collar occupation against the alternative of a blue collar occupation. A binary probit model is used to analyse the conditional probability ${ }^{3}$.

The longitudinal data set allows for the use of panel econometric methods to control for unobserved heterogeneity. However, because of the incidental parameters problem (Neyman \& Scott 1948; Lancaster 2000; Cameron \& Trivedi 2005) this has to be modeled as a random effect probit ${ }^{4}$. Further, other factors would indicate that the random effect specification is appropriate. Some important conditioning variables are fixed for cross sections over the time period, negating

\footnotetext{
${ }^{3}$ All estimates in the analysis used STATA 10 . The average marginal effects were estimated using the 'margeff' module for STATA, Bartus (2005)

${ }^{4}$ While the probit can not be estimated as a fixed effect specification, there does exist a logit fixed effect specification. Both the logit and probit only differ in scale, however due to the other problems with the fixed effects approach, the random effect specification of the probit is retained.
} 
the fixed effect specification. Finally, the fact that the data source is a comprehensive household survey which, in principle, could be subject to re sampling, favours the random effect specification (Hsiao 2003) . The existence of group wise heterogeneity is tested for by testing the random effects

This analysis will make use of various control variables such as industry, country of origin, marital status, geographic location and time period in order to control for factors which may bias the estimates. Due to the often found differences between males and females in labour market outcomes, a binary variable represent female is interacted with all the variables in order to assess. A series of Wald's tests will be employed to test with these interactions are jointly significant overall, by variable group, and whether the effect for females is significantly different from zero.

Due to the nonlinear nature of the probit model, the coefficients are not directly interpretable as any constant magnitude of the effects as the magnitude varies with the value of all the independent variables. The standard approach is to render the magnitude of these effect understandable is the computation of the marginal effects at the means, that is what is the effect of a one unit change of a particular independent variable given that all independent variables are at their respective means (Cameron \& Trivedi 2005). This analysis shall instead compute the average marginal effects using the margeff module for STATA (see Bartus 2005). Average marginal effects are simply the average of the marginal effect computed for each observation within the sample, averaged. Due to averages being the best single measure of central tendency, that is the measure that minimizes the error for the entire sample; the average marginal effects is 
the best, single, measure of the marginal effect of a non-linear regression models. The average marginal effects is more realistic in that it evaluates all observations and not just those at the means which can be biased approximations (Bartus 2005).The average marginal effects can also be interpreted in the same manner as the coefficients of a linear regression model except in that these effects are on average. The discussion of the results will make use of these average marginal effects to characterize the relative magnitude of the effects.

This methodology section has disclosed and discussed the approach used to econometrically assess the relationship between the determinants of occupational choice and the occupational outcome within the white collar and blue collar dichotomy. The analysis will use a random effects probit to control for unobserved heterogeneity and compute average marginal effects to characterize the non-linear effects of the variables with the best single measure.

\section{Results}

The results for the estimations of the random effect probit model are reported in Table 5. This table contains the coefficients for the estimated model including the parameter representing the random effect specification and the average marginal effects for all the models. Likelihood ratio tests for the significance of the random effects specification parameter $(\rho)$ reject the null of $\rho=0$ at all conventional levels of significance, indicating that the random effects panel specification is preferred to a pooled model. 
Table 5: Coefficients and average marginal effects for white collar and blue collar random effects probit regressions

\begin{tabular}{|c|c|c|c|c|}
\hline Variable & Coefficients & $\begin{array}{l}\text { Female Interaction } \\
\text { coefficients }\end{array}$ & AME & $\begin{array}{l}\text { AME for female } \\
\text { interaction }\end{array}$ \\
\hline \multicolumn{5}{|l|}{ Age } \\
\hline Age & $0.1775^{\star \star \star}$ & -0.0291 & $0.0213^{\star \star \star}$ & -0.0035 \\
\hline age squared & $-.00018^{\star \star \star}$ & 0.0002 & $-0.0002^{\star \star \star}$ & 0.0000 \\
\hline \multicolumn{5}{|l|}{ Marital status } \\
\hline Single & baseline & baseline & baseline & baseline \\
\hline Married & $0.4807^{\star \star \star}$ & -0.1901 & $0.0581^{* \star *}$ & -0.0227 \\
\hline De facto & 0.0771 & -0.0829 & 0.0094 & -0.0100 \\
\hline Separated & 0.0376 & -0.0263 & 0.0046 & -0.0032 \\
\hline Divorced & $-0.4294^{\star \star}$ & $0.6068^{\star \star}$ & $-0.0530^{\star \star}$ & $0.0713^{\star \star}$ \\
\hline Widow & $1.3965^{\star \star}$ & $-1.6555^{\star \star}$ & $0.1533^{\star \star}$ & $-0.2060^{\star \star}$ \\
\hline \multicolumn{5}{|l|}{ State } \\
\hline NSW & baseline & baseline & baseline & baseline \\
\hline VIC & 0.0384 & -0.0410 & 0.0046 & -0.0049 \\
\hline QLD & -0.0650 & -0.2871 & -0.0079 & -0.0344 \\
\hline SA & -0.0978 & 0.4288 & -0.0119 & 0.0500 \\
\hline WA & -0.0318 & 0.1643 & -0.0038 & 0.0194 \\
\hline TAS & -0.2166 & -0.2435 & -0.0263 & -0.0291 \\
\hline NT & 0.4412 & -0.4293 & 0.0523 & -0.0516 \\
\hline ACT & $1.053^{\star \star \star}$ & $-1.5853^{\star \star \star}$ & $0.1197^{\star \star \star}$ & $-0.1958^{\star \star \star}$ \\
\hline \multicolumn{5}{|l|}{ Education } \\
\hline PhD or Masters & $3.6851^{\star \star \star}$ & $-1.8741^{\star \star \star}$ & $0.2283^{\star \star \star}$ & $-0.2364^{\star \star \star}$ \\
\hline Graduate diploma & $2.0298^{\star \star \star}$ & -0.5377 & $0.1960^{\star \star \star}$ & -0.0679 \\
\hline Bachelor degree & $1.8577^{\star \star \star}$ & $-0.5654^{\star \star}$ & $0.1879^{\star \star \star}$ & $-0.0714^{\star \star}$ \\
\hline Advanced diploma & $0.7384^{\star \star \star}$ & -0.1776 & $0.0984^{\star \star \star}$ & -0.0223 \\
\hline Certificate 3 or 4 & $-0.8926^{\star \star \star}$ & $0.6617^{\star \star \star}$ & $-0.1532^{\star \star \star}$ & $0.0799^{\star \star \star}$ \\
\hline Certificate 1 or 2 & $-1.5862^{\star \star *}$ & 0.7189 & $-0.2860^{\star \star \star \star}$ & 0.0865 \\
\hline Certificate NA & 0.0145 & -0.4559 & 0.0022 & -0.0575 \\
\hline Year 12 & baseline & Baseline & baseline & baseline \\
\hline Year 11 or less & $-1.2423^{\star \star}$ & $0.4228^{\star \star}$ & $-0.2195^{\star \star \star}$ & $0.0518^{\star \star}$ \\
\hline \multicolumn{5}{|l|}{ Personality } \\
\hline Agreeableness & $-0.1148^{\star}$ & 0.0856 & $-0.01379^{\star}$ & 0.0103 \\
\hline Conscientiousness & $0.1473^{\star \star \star}$ & 0.1149 & $0.01769^{\star \star \star \star}$ & 0.0138 \\
\hline Emotional stability & $0.1310^{\star \star}$ & $-.02121^{\star \star \star}$ & $0.01573^{\star \star}$ & $-0.0255^{\star \star \star}$ \\
\hline Extraversion & 0.0043 & 0.0277 & 0.0005 & 0.0033 \\
\hline Openness & $.1951^{\star \star \star}$ & $-0.1930^{\star \star \star}$ & $0.02344^{\star \star \star}$ & $-0.0232^{\star \star}$ \\
\hline \multicolumn{5}{|l|}{ Parent Status } \\
\hline Dad is white-collar & $0.4769^{\star \star \star}$ & -0.2475 & $0.05899^{\star \star \star}$ & -0.0294 \\
\hline Mum is white-collar & 0.1091 & -0.2168 & 0.0132 & -0.0258 \\
\hline Father's ANU4 & 0.0036 & 0.0004 & 0.0004 & 0.0001 \\
\hline Mother's ANU4 & 0.0024 & 0.0010 & 0.0003 & 0.0001 \\
\hline \multicolumn{5}{|l|}{ Time periods } \\
\hline $\mathrm{t} 1$ & baseline & baseline & baseline & baseline \\
\hline $\mathrm{t} 2$ & 0.0634 & 0.0081 & 0.0076 & 0.0010 \\
\hline $\mathrm{t} 3$ & -0.0104 & 0.1782 & -0.0013 & 0.0214 \\
\hline t4 & 0.0114 & 0.1698 & 0.0014 & 0.0203 \\
\hline $\mathrm{t} 5$ & 0.0163 & 0.1467 & 0.0020 & 0.0176 \\
\hline $\mathrm{t} 6$ & -0.0344 & $0.2322^{\star \star}$ & -0.0041 & $0.0277^{\star \star}$ \\
\hline \multicolumn{5}{|l|}{ Industry } \\
\hline Agriculture & $0.9545^{\star \star \star}$ & $-1.3926^{\star \star \star}$ & $0.1562^{\star \star \star}$ & $-0.1696^{\star \star \star}$ \\
\hline Mining & 0.0812 & -0.4673 & 0.0140 & -0.0545 \\
\hline Manufacturing & baseline & baseline & baseline & baseline \\
\hline Gas \& water & 0.2359 & 0.8268 & 0.0404 & 0.0876 \\
\hline Electricity & $-0.8813^{\star \star \star}$ & $1.9267^{\star \star \star}$ & $-0.1521^{\star \star \star}$ & $0.1763^{\star \star \star}$ \\
\hline Construction & $-6.2882^{\star \star \star *}$ & 0.0204 & $-0.6251^{\star \star \star}$ & 0.0023 \\
\hline Wholesale & -0.1088 & $-1.6708^{\star \star \star}$ & -0.0188 & $-0.2057^{\star \star \star}$ \\
\hline Retail & $1.6327^{\star \star \star}$ & $-0.9049^{\star \star \star}$ & $0.2453^{\star \star \star}$ & $-0.1078^{\star \star \star}$ \\
\hline Transport & -0.0358 & -0.2254 & -0.0062 & -0.0259 \\
\hline Communication & 0.0053 & -0.3262 & 0.0009 & -0.0377 \\
\hline Finance & $3.1293^{\star \star *}$ & $-0.9010^{*}$ & $0.3476^{\star \star \star}$ & $-0.1074^{\star}$ \\
\hline Property & $1.2490^{\star \star \star}$ & $-0.7166^{\star \star \star}$ & $0.1980^{\star \star \star}$ & $-0.0846^{\star \star \star}$ \\
\hline Government & $1.1453^{\star \star \star}$ & -0.0694 & $0.1784^{\star \star \star}$ & -0.0079 \\
\hline Education & $1.9891^{\star \star \star}$ & 0.1059 & $0.2812^{\star \star \star}$ & 0.0119 \\
\hline Health & $1.9907^{\star \star \star}$ & -0.1895 & $0.2813^{\star \star \star}$ & -0.0217 \\
\hline Culture & $0.9818^{\star \star \star}$ & -0.0590 & $0.1602^{\star \star *}$ & -0.0067 \\
\hline Personal & $0.7380^{\star \star \star}$ & $-0.7103^{\star \star \star}$ & $0.1230^{\star \star \star}$ & $-0.0838^{\star \star}$ \\
\hline \multicolumn{5}{|l|}{ Country of origin } \\
\hline Australia & baseline & baseline & baseline & baseline \\
\hline English speaking nation & 0.1511 & -0.3653 & 0.0181 & -0.0438 \\
\hline Non English speaking nation & -0.1543 & $-0.6036^{\star \star}$ & -0.0186 & $-0.0729^{\star \star}$ \\
\hline \multicolumn{5}{|l|}{ Other parameters } \\
\hline $\begin{array}{l}\text { Constant (and female intercept } \\
\text { shift parameter) }\end{array}$ & $-6.5155^{\star \star \star}$ & $3.4467^{\star \star \star}$ & & $0.4364^{\star \star \star}$ \\
\hline Rho & $1.3150^{\star \star \star}$ & & & \\
\hline Legend & $*: \mathrm{p}<0.1$ & $* *: \mathrm{p}<0.05$ & $* * *: \mathrm{P}<0.01$ & \\
\hline
\end{tabular}


Females, as have a higher probability of approximately 0.43 over males of achieving a white collar occupation. As previously stated, white collar occupations are not necessary superior occupations even though many of the higher occupations are classified as white collar. Due to social conventions occupations which are white collar, but not of high status, may be dominated by females. That is this probability of a female occupying a white collar job may not reflect higher occupational status.

With respect to human capital theory both age and education were found to have a significant effect on occupational attainment. Age is found to have a significantly positive effect on the probability of being white collar but this effect decreases as individuals get older with no differences between the genders. University level education, such as bachelor, graduate diploma, masters and doctorates, and the non-university tertiary education of an advanced diploma all increase the probability of an individual attaining a white collar occupation. Conversely, tertiary education such as certificates 1 through 4 and having less than year 12 education have a statistically significant and negative effect the probability of attaining a white collar occupation compared to a complete high school education. The effect of a lack of completed high school education leads to unskilled occupations and individuals who acquire certificates are trade focused and are more likely to enter higher status blue collar occupations. The gender interaction effects show that with regards to $\mathrm{PhD}$ or masters, Bachelor, Certificate 3 or 4, having an incomplete high school education is statistically significant, negative but to a lesser magnitude than the male effect. This suggests that education has a lesser effect on influencing the outcome of females between these two outcomes. 
Binary variables associated with industry, state, and time period are significant, suggesting that many of the effects on occupational outcomes are driven by industrial composition, which is reinforced by the state because of the regional concentration of industries. It should be noted that the only state significant is the ACT which is a highly specialised regions which primarily provides for the federal government. The binary variable for country of origin shows that migrants from a non-English speaking country who are female are less likely to be in a white collar occupation by 0.07

Turning to dynasty hysteresis measures, parental status produces interesting effects on individual occupational outcomes. We found only the binary variable representing a father's status in either a white collar occupation to take on statistical significance. This effect was consistent across both gender and caused individuals to have a 0.06 increase on their chance of being in a white collar occupation. Comparing the size of this effect to human education finds that it is dramatically smaller with effects to about a half to a quarter than those found with human capital variables.

Personality, as measured by the five factor model, is the focus of the paper. Four of the five personality traits, all except extraversion, have a highly significant effect on the occupational outcome; however these effects vary between the genders. Conscientiousness - the trait associated with persistence, punctuality, hard work, etc.- is found to have a highly significant and positive effect on occupational achievement for both genders. That is, increasing conscientiousness raises the probability of being in a white collar occupation. This finding is consistent with the previous literature both in economics and psychology. Individuals with the 
highest levels of conscientiousness can enjoy an additional bonus of about 0.108 (a marginal effect of $0.018 \times 6$ ) in their probability of achieving a white collar occupation compared with their lowest conscientiousness counterparts. This bonus can be seen as almost equal to a bachelor degree for females and about half of one for males. Openness -the traits associated with the desire for new experiences and ideas has also achieved statistical significance but only for the males as the sum of the coefficient for the male and female interactive term fails to reject the null hypothesis at being equal to zero at all conventional levels. As previously mentioned, openness has been hypothesized to act through the desire of an individual to learn and be trained (Barrick \& Mount 1991). The effect of openness is larger than the effect for conscientiousness. The effect of openness in the male sample is larger an increase the probability of being in a white collar occupation by $0.14(0.023 \times 6)$. Emotional stability is another variable that is only significant effect to males with the female interaction. Emotional stability, the negative of neuroticism, which shows how easily negative emotions affects an individual, carries a positive impact suggesting that males who react less emotionally have an increased probability of being in a white collar occupation. Emotional stability effect on males is close to the same as the effect of conscientiousness. Agreeableness, that is the ability to get along, has a less significant effect at the $10 \%$ level compared to the other personality traits and carries a negative effect but only for males. This suggests that agreeableness is not desirable in white collar occupations and an individual who is agreeable is less likely to obtain these jobs. The agreeableness results seem to coincide with the findings of Mueller and Plug (2004) that the absence of agreeableness may help to negotiate wages and in the achievement of an individual's objectives. Personality effects can be seen as having an impact that may rivals education. This effects are pronounced when an individual posses high combinations of these personality traits. Given the smaller effect of 
education and the relatively large effect of conscientiousness for females, it can be suggested that conscientiousness matters more to females than it does for males due to a lack of ways in which a female can compensate for deficiencies in personality traits through education. This finding can be seen qualitatively similar to that of Heckman, Stixrud \& Urzua (2006) in that they find that non cognitive factors, as opposed to cognitive factors, have a greater effect for females than males in occupational attainment.

\section{Conclusion}

This paper focused on the examination of personality factors, parental social status, and human capital on the attainment of a white collar occupation. The analysis used the HILDA panel survey data to estimate a random effects probit model. In addition to finding non-linear in education in terms of the probability of being in a white collar occupation, we found that the effects of personality may potentially rival but are generally smaller than that of education whilst parental status has a minimal effect. Interactive binary variable were used to estimate seperate marginal effects for males and females and in these models indicate that female occupational attainment is less sensitive to characteristics and that the personality trait of conscientiousness is important. Future work will examine occupations with a larger number of nominal outcomes; make use of advancement in the econometrics of occupational choice that allow for supply and demand decompositions, and will explore the optimal specification of the model. These refinements will lead to more detailed and precise estimates of the effects of personality and parental status on occupational choice. 


\section{References}

Akerlof, G. A. 1997, 'Social distance and social decisions.' Econometrica, Vol. 65, No. 5, pp. 1005-1027.

Amemiya, T. 1981, 'Qualitative response models: a survey.' Journal of Economic Literature, Vol. 19, No. 4, pp. 1483-1536.

Australian Bureau of Statistics \& Australian Department of Employment Education Training and Youth Affairs 1997. ASCO : Australian standard classification of occupations, Canberra, Australian Bureau of Statistics.

Barrick, M. R. \& Mount, M. K. 1991, 'The big five personality dimensions and job performance: a meta-analysis.' Personnel Psychology, Vol. 44, No. 1, pp. 1-26.

Barrick, M. R., Mount, M. K. \& Gupta, R. 2003, 'Meta-analysis of the relationship between the five-factor model of personality and Holland's occupational types.' Personnel Psychology, Vol. 56, No. 1, pp. 45-74.

Bartus, T. 2005, 'Estimation of marginal effects using margeff.' The Stata Journal, Vol. 5, No. 3, pp. 309-329.

Becker, G. S. 1993. Human capital: a theoretical and empirical analysis, with special reference to education, Chicago, The University of Chicago Press.

Becker, G. S. 1996. Accounting for tastes, Cambridge, Massachusetts, Harvard University Press.

Bjerk, D. 2007, 'The differing nature of black-white wage inequality across occupational sectors.' Journal of Human Resources, Vol. 42, No. 2, pp. 398-434.

Blanden, J., Gregg, P. \& Macmillan, L. 2007, 'Accounting for intergenerational income persistence: noncognitive skills, ability and education.' The Economic Journal, Vol. 117, No. 519, pp. C43-C60.

Blau, P. M., Gustad, J. W., Jessor, R., Parnes, H. S. \& Wilcock, R. C. 1956, 'Occupational choice: a conceptual framework.' Industrial and Labor Relations Review, Vol. 9, No. 4, pp. 531-543.

Borghans, L., Duckworth, A., Heckman, J. J. \& ter weel, B. 2008, The economics and psychology of personality traits, NBER Working Papers, Cambridge, Massachusetts

Borooah, V. K. 2001, 'How do employees of ethnic origin fare on the occupational ladder in Britian?', Scottish Journal of Political Economy, Vol. 48, No. 1, pp. 1-26.

Borooah, V. K. \& Iyer, S. 2005, 'The decomposition of inter-group differences in a logit model: Extending the Oaxaca-Blinder approach with an application to school enrolment in India.' Journal of Economic \& Social Measurement, Vol. 30, No. 4, pp. 279-293. 
Borooah, V. K. \& Mangan, J. 2002, 'An analysis of occupational outcomes for indigenous and asian employees in Australia.' The Economic Record, Vol. 78, No. 1, pp. 31-49.

Boskin, M. J. 1974, 'A conditional logit model of occupational choice.' The Journal of Political Economy, Vol. 82, No. 2, pp. 389-398.

Botticini, M. \& Eckstein, Z. V. I. 2005, 'Jewish occupational selection: education, restrictions, or minorities?', The Journal of Economic History, Vol. 65, No. 04, pp. 922-948.

Bowles, S. \& Gintis, H. 2002, 'The inheritance of inequality.' Journal of Economic Perspectives, Vol. 16, No. 3, pp. 3-30.

Bowles, S., Gintis, H. \& Osborne, M. 2001a, 'The determinants of earnings: a behavioral approach.' Journal of Economic Literature, Vol. 39, No. 4, pp. 1137.

Bowles, S., Gintis, H. \& Osborne, M. 2001b, 'Incentive-enhancing preferences: personality, behavior, and earnings.' American Economic Review, Vol. 91, No. 2, pp. 155-158.

Bradley, S. 1991, 'An empirical analysis of occupational expectations.' Applied Economics, Vol. 23, No. 7, pp. 1159.

Brandstätter, H. 1997, 'Becoming an entrepreneur: a question of personality structure?', Journal of Economic Psychology, Vol. 18, No. 2-3, pp. 157-177.

Bratti, M. \& Mancini, L. 2003, Differences in early occupational earnings of UK male graduates by degree subject: evidence from the 1980-1993 USR, IZA Discussion Paper Series,

Cameron, A. C. \& Trivedi, P. K. 2005. Microeconometrics : methods and applications, New York, NY, Cambridge University Press.

Caplan, B. 2003, 'Stigler-Becker versus Myers-Briggs: why preference-based explanations are scientifically meaningful and empirically important.' Journal of Economic Behavior \& Organization, Vol. 50, No. 4, pp. 391-405.

Carol, A. \& Parry, S. 1969, 'The economic rationale of occupational choice: reply.' Industrial \& Labor Relations Review, Vol. 22, No. 3, pp. 428-430.

Cawley, J., Conneely, K., Heckman, J. J. \& Vytlacil, E. 1997, 'Cognitive ability, wages, and meritocracy', in Intelligence, genes, and success : scientists respond to "The bell curve". B. Devlin Springer, New York.

Cawley, J., Heckman, J. \& Vytlacil, E. 2001, 'Three observations on wages and measured cognitive ability.' Labour Economics, Vol. 8, No. 4, pp. 419-442.

Child, D. 2006. The essentials of factor analysis, New York, Continuum.

Cole, K. 2007, Good for the soul: the relationship between work, wellbeing and psychological capital, $\mathrm{PhD}$ in Economics, University of Canberra 
Connolly, S., Micklewright, J. \& Nickell, S. 1992, 'The occupational success of young men who left school at sixteen.' Oxford Economic Papers, Vol. 44, No. 3, pp. 460-479.

Constant, A. \& Zimmermann, K. F. 2003, Occupational choice across generations, IZA Discussion papers, Bonn, Germany

Croll, P. 2008, 'Occupational choice, socio-economic status and educational attainment: a study of the occupational choices and destinations of young people in the British Household Panel Survey.' Research Papers in Education, Vol. iFirst Article, pp. 1 - 26.

Darden, J. 2005, 'Black occupational achievement in the Toronto census metropolitan area: does race matter?', Review of Black Political Economy, Vol. 33, No. 2, pp. 31-54.

Doepke, M. \& Zilibotti, F. 2005, 'Social class and the spirit of capitalism.' Journal of the European Economic Association, Vol. 3, No. 2/3, pp. 516-524.

Ehrenberg, R. G. \& Smith, R. S. 2006. Modern labour economics: theory and public policy, Pearson Education.

Filer, R. K. 1983, 'The role of personality and tastes in determining occupational structure.' Industrial \& Labor Relations Review, Vol. 39, No. 3, pp. 412.

Friedman, M. 2007. Price theory, New Brunswick, NJ, Transaction Publishers.

Furnham, A. \& Fudge, C. 2008, 'The five factor model of personality and sales performance.' Journal of Individual Differences, Vol. 29, No. 1, pp. 11-16.

Goldberg, L. R. 1993, 'The structure of phenotypic personality traits.' American Psychologist, Vol. 48, No. 1, pp. 26-34.

Groves, M. O. 2005, 'How important is your personality? Labor market returns to personality for women in the US and UK.' Journal of Economic Psychology, Vol. 26, No. 6, pp. 827841.

Haisken-DeNew, J. P. \& Hahn, M. 2006, Panelwhiz: A flexible modularized stata interface for accessing large scale panel data sets, http://www.panelwhiz.eu,

Harper, B. \& Haq, M. 2001, 'Ambition, discrimination, and occupational attainment: a study of a British cohort.' Oxford Economic Papers, Vol. 53, No. 4, pp. 695.

Heckman, J. J. 2008, Schools, skills and synapses, IZA discussion paper series, Bonn, Germany

Heckman, J. J., Lochner, L. \& Todd, P. E. 2003, Fifty years of Mincer earnings regressions, NBER Working papers, Cambridge, Massachusetts

Heckman, J. J. \& Rubinstein, Y. 2001, 'The importance of noncognitive skills: lessons from the GED testing program.' American Economic Review, Vol. 91, No. 2, pp. 145-149. 
Heckman, J. J., Stixrud, J. \& Urzua, S. 2006, 'The effects of cognitive and noncognitive abilities on labor market outcomes and social behavior.' Journal of Labor Economics, Vol. 24, No. 3, pp. 411.

Hellman, D. A. 1980. The economics of crime, New York, St. Martin's Press.

Hennessy, T. C. \& Rehman, T. 2007, 'An investigation into factors affecting the occupational choices of nominated farm heirs in Ireland.' Journal of Agricultural Economics, Vol. 58, No. 1, pp. 61-75.

Hsiao, C. 2003. Analysis of panel data, Cambridge ; New York, Cambridge University Press.

Jones, F. L. \& McMillan, J. 2001, 'Scoring occupational categories for social research: A review of current practice, with Australian examples.' Work Employment Society, Vol. 15, No. 3, pp. 539-563.

Junankar, P. N. \& Mahuteau, S. p. 2005, 'Do migrants get good jobs? New migrant settlement in Australia.' Economic Record, Vol. 81, pp. S34-S46.

Kaufman, B. E. \& Hotchkiss, J. L. 2006. The economics of labor markets, Mason, OH, Thomson/South-Western.

Laband, D. N. \& Lentz, B. F. 1983, 'Like father, like son: toward an economic theory of occupational following.' Southern Economic Journal, Vol. 50, No. 2, pp. 474.

Lancaster, T. 2000, 'The incidental parameter problem since 1948.' Journal of Econometrics, Vol. 95, No. 2, pp. 391-413.

Larson, L. M., Rottinghaus, P. J. \& Borgen, F. H. 2002, 'Meta-analyses of big six interests and big five personality factors.' Journal of Vocational Behavior, Vol. 61, No. 2, pp. 217-239.

Le, A. T. \& Miller, P. W. 2001, 'Occupational status: why do some workers miss out?', Australian Economic Papers, Vol. 40, No. 3.

Leigh, A. 2008, 'Returns to education in Australia.' Economic papers, Vol. 27, No. 3, pp. 233.

Losoncz, I. (2007). Personality Traits in HILDA. HILDA survey research conference. University of Melbourne.

Mahuteau, S. \& Junankar, P. N. 2008, Do migrants get good jobs in Australia? The role of ethnic networks in job search, IZA Discussion paper series, Bonn, Germany

McCrae, R. R. \& Costa, P. T. 2003. Personality in adulthood : a five-factor theory perspective, New York, Guilford Press.

Meng, X. \& Miller, P. 1995, 'Occupational segregation and its impact on gender wage discrimination in china's rural industrial sector.' Oxford Economic Papers, Vol. 47, No. 1, pp. 136-155. 
Mincer, J. 1974. Schooling, experience, and earnings, New York,, National Bureau of Economic Research.

Montmarquette, C., Cannings, K. \& Mahseredjian, S. 2002, 'How do young people choose college majors?', Economics of Education Review, Vol. 21, No. 6, pp. 543-556.

Mueller, G. \& Plug, E. 2004, Estimating the effect of personality on male-female earnings, IZA discussion paper,

Mwabu, G. \& Evenson, R. E. 1997, 'A model of occupational choice applied to rural Kenya.' African Development Review, Vol. 9, No. 2, pp. 1-14.

Nasir, Z. M. 2005, 'An analysis of occupational choice in Pakistan: a multinomial approach.' The Pakistan Development Review, Vol. 44, No. 1, pp. 57-79.

Neal, D. 1995, 'Industry-specific human capital: evidence from displaced workers.' Journal of Labor Economics, Vol. 13, No. 4, pp. 653.

Neyman, J. \& Scott, E. L. 1948, 'Consistent estimates on partially consistent observations.' Econometrica, Vol. 16, No. 1, pp. 1.

Nyhus, E. K. \& Pons, E. 2005, 'The effects of personality on earnings.' Journal of Economic Psychology, Vol. 26, No. 3, pp. 363-384.

Orazem, P. F. \& Mattila, J. P. 1991, 'Human capital, uncertain wage distributions, and occupational and educational choices.' International Economic Review, Vol. 32, No. 1, pp. 103-122.

Ozer, D. J. \& Benet-Martinez, V. 2006, 'Personality and the prediction of consequential outcomes.' Annual Review of Psychology, Vol. 57, No. 1, pp. 401-421.

Paglin, M. \& Rufolo, A. M. 1990, 'Heterogeneous human capital, occupational choice, and malefemale earnings differences.' Journal of Labor Economics, Vol. 8, No. 1, pp. 123-144.

Pal, S. \& Kynch, J. 2000, 'Determinants of occupational change and mobility in rural India.' Applied Economics, Vol. 32, No. 12, pp. 1559-1573.

Park, J. H. 1999, 'Estimation of sheepskin effects using the old and the new measures of educational attainment in the Current Population Survey.' Economics Letters, Vol. 62, No. 2, pp. 237-240.

Porter, S. R. \& Umbach, P. D. 2006, 'College major choice: an analysis of person-environment fit.' Research in Higher Education, Vol. 47, No. 4, pp. 429-449.

Rosenbloom, J. L., Ash, R. A., Dupont, B. \& Coder, L. 2008, 'Why are there so few women in information technology? Assessing the role of personality in career choices.' Journal of Economic Psychology, Vol. 29, No. 4, pp. 543-554. 
Sacerdote, B. 2005, 'Slavery and the intergenerational transmission of human capital.' Review of Economics \& Statistics, Vol. 87, No. 2, pp. 217-234.

Saucier, G. 1994, 'Mini-markers: a brief version of Goldberg's unipolar big-five markers.' Journal of Personality Assessment, Vol. 63, No. 3, pp. 506.

Schmidt, P. \& Strauss, R. P. 1975, 'The prediction of occupation using multiple logit models.' International Economic Review, Vol. 16, No. 2, pp. 471-486.

Schweitzer, S. O. 1971, 'Occupational choice, high school graduation, and investment in human capital.' Journal of Human Resources, Vol. 6, No. 3, pp. 321-332.

Semykina, A. \& Linz, S. J. 2007, 'Gender differences in personality and earnings: evidence from Russia.' Journal of Economic Psychology, Vol. 28, No. 3, pp. 387-410.

Shaw, K. L. 1984, 'A formulation of the earnings function using the concept of occupational investment.' The Journal of Human Resources, Vol. 19, No. 3, pp. 319-340.

Stevens, M. 2003, 'Earnings functions, specific human capital, and job matching: tenure bias Is negative.' Journal of Labor Economics, Vol. 21, No. 4, pp. 783-805.

Swope, K. J., Cadigan, J., Schmitt, P. M. \& Shupp, R. 2008, 'Personality preferences in laboratory economics experiments.' Journal of Socio-Economics, Vol. 37, No. 3, pp. 9981009.

Tachibanaki, T. 1980, 'Education, occupation and earnings : a recursive approach for France.' European Economic Review, Vol. 13, No. 1, pp. 103-127.

Tsukahara, I. 2007, 'The effect of family background on occupational choice.' Labour, Vol. 21, No. 4-5, pp. 871-890.

Turner, S. E. \& Bowen, W. G. 1999, 'Choice of major: the changing (unchanging) gender gap.' Industrial and Labor Relations Review, Vol. 52, No. 2, pp. 289-313.

Veblen, T. 1998. The theory of the leisure class, Amherst, NY, Prometheus Books.

Author (Ed^), HILDA user manual - release 6, Melbourne institute of applied economic and social research, University of Melbourne,

Yu, P. 2004, Return to education for Australian male workers: an estimate with HILDA, Paper for case studies in applied econometrics, Canberra

Yuhong, D. \& Johnes, O. 2003, 'Influence of expected wages on occupational choice: new evidence from Inner Mongolia.' Applied Economics Letters, Vol. 10, No. 13, pp. 829832. 